\title{
GALERI TUBUH DAN RUANG DI MANGGA BESAR
}

\author{
Chastellia Marshelle Nery ${ }^{1)}$, Agustinus Sutanto ${ }^{2)}$ \\ 1) Program Studi S1 Arsitektur, Fakultas Teknik, Universitas Tarumanagara, chastellya@gmail.com \\ 2)Program Studi S1 Arsitektur, Fakultas Teknik, Universitas Tarumanagara, berpikirteoripraksis@gmail.com
}

\begin{abstract}
Abstrak
Mangga Besar memiliki citra kawasan yang terkenal akan kehidupan malamnya. Kawasan ini juga memiliki anomali yang sudah menjadi rahasia umum yaitu tempat pelacuran. Terambil dari gambaran isu prostitusi yang mewujudkan bahwa adanya tubuh yang secara konotasi "dihargai" dengan kriteria standar tertentu (cantik, sexy, dll). Sama halnya dengan kehidupan sosial sehari-hari yang dihadapi dengan adanya standar nilai sosial tertentu mengenai penampilan dan bentuk tubuh sebagai body goals. Sehingga tak sedikit orang mengalami insecurity dengan tubuh mereka sendiri, dan dampaknya ada gejala psikologis akan self-acceptance yang rendah, body shaming, non-equality, dll. Proyek memiliki visi untuk menunjukkan akan keberagaman tubuh manusia, setiap tubuh dan kondisi manusia mencerminkan identitas diri sehingga bertujuan meningkakan pengetahuan mengenai body acceptance as a value dengan mendukung adanya gerakan body positivity. Misi menciptakan sebuah ruang yang mendukung pertumbuhan komunitas di dalamnya yang bertemakan body and space, yang dimana hubungan antara tubuh manusia yang membentuk ruangnya sendiri melalui gerakan yang terbentuk sebagai ekspresi dari diri dan dimana tubuh disini adalah aktor utama dari sebuah ruang arsitektur. Dengan menerapkan metode pattern laguange dan tipe ruang kegiatan sebagai pola diharapkan dapat membantu menerjemahkan ruang dari visi yang ingin diciptakan. Selain itu dijadikan sebagai fasilitas third place yang menunjang untuk kawasan, sehingga dibentuknya sebuah gallery yang memiliki 3 program utama yaitu adanya education, entertainment, dan socialize.
\end{abstract}

Kata kunci: Ekspresi; Komunitas; Ruang Sosial; Tubuh

\begin{abstract}
Mangga Besar has an image of the region which is famous for its nightlife and culinary tourism in it, this area also has an anomaly that has become a public secret which is a brothel. Taken from the description of the issue of prostitution that embodies, there is a body that connotations are "valued" by certain standard criteria (beauty, sexy, etc.) Similarly, everyday social life is faced with the existence of certain social value standards regarding the appearance and shape of the body as body goals. So that not a few people experience insecurity with their own bodies, and the impact is there are psychological symptoms of low self-acceptance, body shaming, non-equality, etc. The project has a vision to show the diversity of the human body, each body and condition of the human being to create self-identity so that it aims to increase knowledge about body acceptance as a value by supporting the existence of body positivity. By using pattern language method and type of activity space as a typology that hoped it can help to translate the space from the projects background. The mission is to create a space that supports the growth of the community within them with the theme is body and space, which is the relationship between the human body that forms its own space through movements that are formed as expressions of self and where the body here is the main actor of an architectural space. Besides that, it is also used as a third place facility that supports the region, so this gallery has 3 main programs, education, entertainment, and socialize.
\end{abstract}

\section{Keywords: Body; Community; Expression; Social; Space}




\section{PENDAHULUAN}

Jakarta merupakan salah satu kota besar di Indonesia yang telah mengalami perkembangan dari sebuah keberhasilan ekonomi nasional, dan bersamaan dengan itu muncullah berbagai sarana hiburan yang menjadi daya tarik sendiri di masyarakat. Demi mengimbangi kebutuhan tersebut, hadirlah sarana hiburan malam seperti klub, diskotik, kafe, pub, dan lain-lain. Berawal dari hasil investigasi kawasan di Mangga Besar yang menunjukkan bahwa aktivitas disana sangat aktif menjelang malam hari dan memang disana sudah terkenal akan wisata kulinernya dan gemerlapnya dunia malam. Dunia malam disana memiliki kaitan yang cukup erat dengan skandal isu prostitusi di dalamnya.

Gambaran dari prostitusi secara garis besar memiliki konotasi yang mengarah pada konteks bahwa "tubuh" dinilai dengan standar tertentu dan "dihargai". Yang dimana nilai dan standar itu terbentuk secara natural di masyarakat dan dijadikan sebagai sebuah patokan yang diseut dengan body goals. Tak sedikit orang mengalami insecurity dalam diri mereka karena hal tersebut. Dampak yang ditimbulkan adalah adanya gejala psikologis akan self-acceptance yang rendah, body shaming, non-equality, dll.

Sebuah thirdplace memiliki beberapa kriteria menurut Ray Oldenburg, yang dimana sebuah tempat ketiga harus netral, playful, inklusif, dan percakapan adalah sebuah aktivitas yang penting sehingga tercipta komunitas di dalamnya. Menciptakan sebuah ruang ketiga berupa gallery yang memiliki tema body and space, ingin mengangkat isu gerakan body positivity yang dilatarbelakangi oleh konsep tubuh yang diberi "nilai". Menyadarkan betapa pentingnya tubuh dan diterjemahkan dalam sebuah ruang dengan mengutamakan hubungan antara tubuh dan ruang sehingga menciptakan sebuah desain ruang yang memiliki nilai "experience" di dalamnya bagi para pengguna. Disamping itu juga memiliki program yang sesuai dengan analisis dan pembahasan tapak yang dapat mendukung kawasan secara neighbourhood facility. Memiliki program utama berupa edukasi, entertainment, dan socialize, yang dapat memberika kesempatan kepada masyarakat untuk memiliki ruang yang dapat mewadahi kegiatan mereka disamping first place dan second place mereka untuk dapat mengembangkan diri, meet the strangers, dan adanya living room dalam sebuah urban society.

\section{KAJIAN TEORI}

\section{The Third Place}

Third Place ditujuan sebagai fungsi tersier (pelengkap) dlaam aktivitas sehari-hari masyarakat, menurut Ray Oldenburg pada bukunya "The Great Good Place (1997)", ada beberapa kriteria penting yang harus ada dalam sebuah third place, yaitu:

a. Neutral ground: Pengunjung bebas mengakses tempat tanpa hambatan apapun

b. Leveler (a leveling place): Tidak terikat dengan status sosial.

c. Conversation is the main activity: Pembicaraan yang menyenangkan antar individu

d. Accessibility and accommodation: Dapat memenuhi kebutuhan penggunanya

e. The regulars: Pengunjung lama dapat menarik pengunjung baru

f. A low profile: Tidak mahal dan sederhana

g. The mood is playful: Memiliki sifat yang menyenangkan

h. A home away from home: Spiritual regeneration

Third place adalah bagian dari komunitas, karena itu aksesibilitas yang mudah menjadi hal yang penting. Karena third place selalu hadir saat dibutuhkan dan memenuhi kebutuhan warganya.

\section{Body and Space}

Arsitektur bukanlah hanya objek yang membeku: di era modern ini kerapkali arsitektur berkonsentrasi pada sebuah karya yang hanya memiliki objek fisik yang berfokus pada kualitas 
visual, contohnya gambar ilustrasi 3d visual yang memiliki impact visual tinggi, dibandingkan dengan kualitas ruang yang diciptakan. Hal ini menajadikan batu sandungan dalam desain, karena menghalang keterlibatan tubuh dalam proses pengalaman ruang. Maka arsitektur sebaiknya tidak hanya memiliki penglaman melalui mata namun seluruh tubuh, penginderaanya, memori dan imajinasi. Bagaimana pengalaman fisik dan fenomenologis bisa bersamaan di rasakan pada sebuah space adalah sebuah dasar cara tubuh kita merasakan arsitektur (space) dan relasi kita dengannya.

Hubungan antara tubuh dan ruang digambarkan memiliki penempatan atau disebut tingkatan diantaranya. Melalui sebuah gerakan tarian dapat dianalogikan hubungan antar keduanya oleh Uysal, V. dan Markus W. dan mengkategorikan hubungan di dalamnya menjadi BODYspace, bodySpace, dan BODYSPACE. Yang dimana BODYspace, tubuh memiliki tingkat dominasi lebih, sehingga tubuh yang membangun kembali ruang untuknya. Sedangkan bodySpace merupakan sebaliknya, tubuhlah yang harus beradaptasi dengan konsep ruang yang terbangun yang dimana membuat ruang mendefinisikan sendiri keberadaanya. bodySpace tidak mebuktikan suatu hubungan yang baik antara tubuh dan ruang karena mengabaikan keberadaan tubuh, yang dimana tubuh adalah pengguna utama dalam sebuah ruang. Terakhir BODYSPACE adalah kondisi dimana tubuh dan ruang terhubung satu sama lain, tidak adanya kesan keutamaan dala tubuh dan ruang. Hubungan ini sangat ideal untuk merancang ruang yang menarik karena pengalaman tubuh serta kualitas ruang keduanya memberikan makna baru.

\section{Movement in Architecture}

Konsep dari sirkulasi adalah kunci utama dalam sebuah arsitektur, yang dimana para arsitek menghubungkan sirkulasi dengan tubuh dari manusia yang bergerak menciptakan sirkulasi. Sirkulasi dalam bangunan diumpakan sebagai sebuah sistem independen yang berada pada sebuh arsitektur yang sama dengan tubuh, arsitek pada umumnya menganggap ini sebagai gambaran pada konsep fungsional. Viollet-le-Duc mengatakan sirkulasi sebagai sesuatu yang mengalir dalam sebuh bangunan tidak terikat oleh satu kesatuan fisik bangunan, namun tak hanya aliran dlaam bangunan tapi juga gerakan tubuh yang dirasakan. Kedua konsep sebagai metaphor aliran pada bangunan dan fungsionalnya merfokus pada efek persepsi ruang yang dihasilkan. Gerakan tubuh yang diproyeksikan yang menghasilkan ruang dan bentuk arsitektur. Bagi mereka, pengalaman arsitektur khususnya gerakan tubuh sangat penting bagi pemahaman tentang bentuk dan komposisi dalam suatu bangunan. Pengaruh psikologi ini terwujud pada awal abad ke-20 dimana arsitek modernis menggunakan strategi seperti, "incline planes, horizontal emphases, acceleration of façade rhytm" dan kurva aerodinamik untuk mengekspresika pergerakan dalam architecture of the body dan pergerakan sekitarnya.

\section{METODE}

\section{Pattern Languange}

Pada buku "A Pattern Language (1977)" oleh Christopher Alexander, ia mengatakan bahwa bahasa pola tersusun dari pola-pola yang kemudian bisa digunakan berulang-ulang karena bersifat utuh dan memiliki makna. Tiap pola mendeksripsikan suatu isu yang utuh, yang muncul berulang pada lingkungan yang kemudian disusun menjadi suatu bahasa yang dimana terjalin suatu pola yang mengatur hubungan antar pola tersebut, sehingga memiliki hasil bangunan dan tempat yang utuh dan koheren. Pola-pola ini memiliki hierarki. Pola yang terjadi saling berhubungan dan pola yang kecil melengkapi pola yang lebih besar, pola terhubung dan melengkapi pola yang lebih besar lagi dan seterusnya. Sehingga hasil dari pola solusi yang dikombinasikan ini dapat sesuai dengan esensi dasarnya. Contoh: dalam membuat daerah hijau yang mudah diakses, diperlukan suatu lingkungan sekitarnya yang dapat mendukung kondisi tersebut misalnya harus dekat dengan keramaian, dapat ditembus, atau memiliki fasilitas yang memadai, dll. Disini menunjukkan bahwa segala sesuatu tidak dapat berdiri sendiri namun didukung oleh sesuatu yang membuatnya menjadi utuh. 


\section{Tipologi Ruang Kegiatan sebagai Pola}

Pola disini dapat berupa program kegiatan yang saling terjalin. Suatu kegiatan memiliki sifat dasar yang menunjukkan adanya konsekuensi terhadap pemakaian ruang dan syarat yang dihasilkannya. Dengan mempelajari kegiatan secara baik berarti ikut menamapiplkan suatu penyelesaian terhadap masalah yang ditimbulkannya. Menganalisis batas ruang gerak harus mengaitkan tipe/ model kegiatan yang terjadi di dalamnya bukan ke nama ruang. Misalnya Toko, bukanlah sebuah tipe kegiatan, namun tipe kegiatannya adalah pertukaran benda dengan sesuatu. Perancang diharapkan dapat melihat peluang lain dari tipe kegiatan sebagai wujud batas ruang yang lebih mendasar, bukan lagi mengacu pada nama toko tersebut.

\section{DISKUSI DAN HASIL}

Dalam proyek gallery of body and space ini, penulis memiliki visi adanya sebuah ruang yang dapat mewadahi aktivitas tersier sehari-hari masyarakat yang sesuai dengan kriteria ruang ketiga. Selain itu juga dapat mengedukasi, menjadi fasilitas ruang terbuka kota yang bersifat permeable dan walkable.

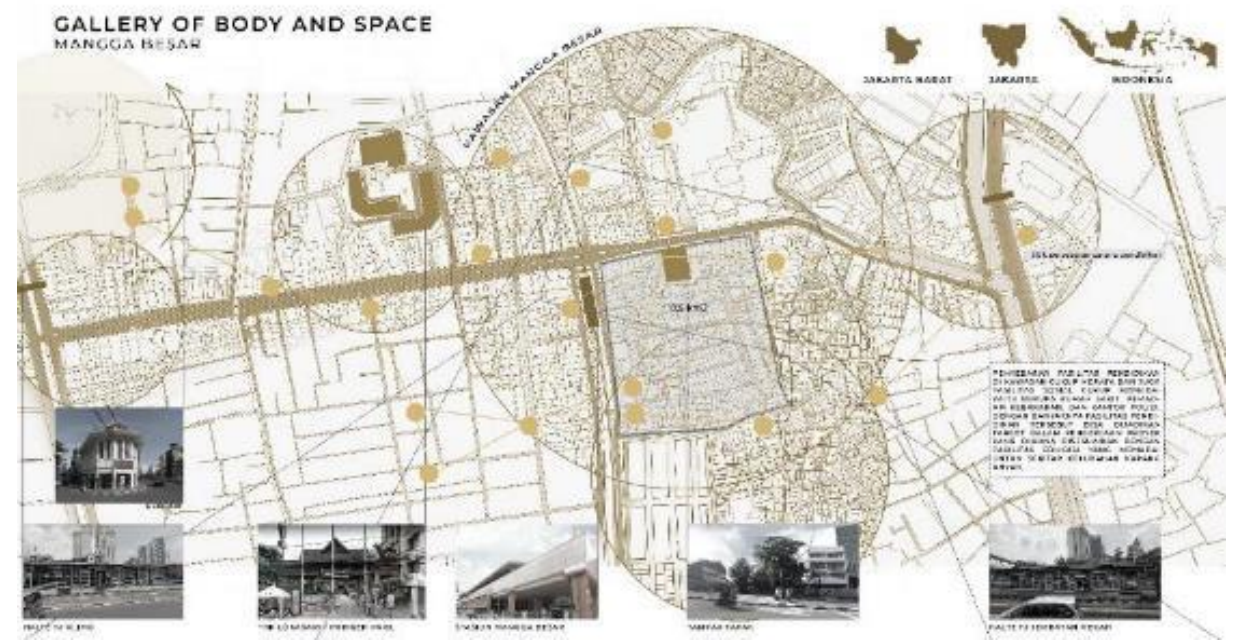

Gambar 1. Kawasan Sekitar Mangga Besar Sumber: Penulis,2020.
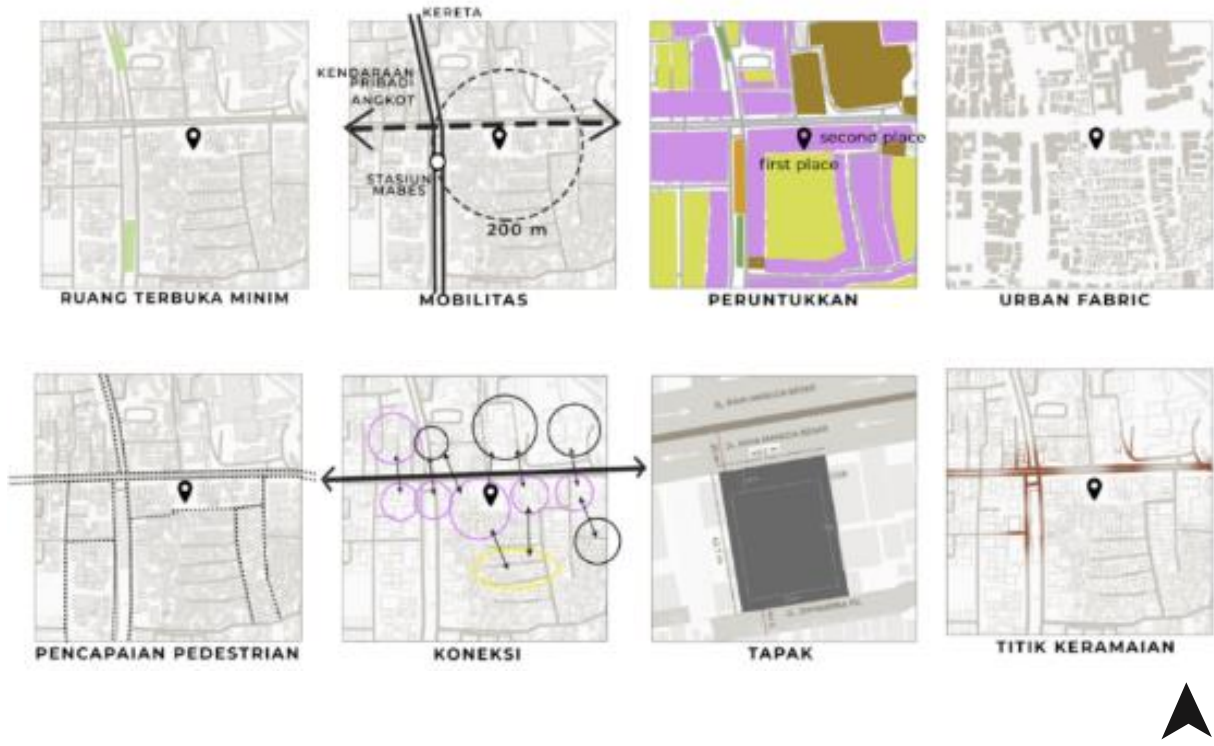

Gambar 2. Informasi Tapak Sumber: Penulis,2020. 
Tapak berada di depan Jl. Raya Mangga Besar, tepatnya berhadapan langsung dengan sekolah Budi Mulia dan Rumah Sakit Husada. Berada pada radius kurang lebih 200 meter dari stasiun Manggar Besar sehingga pencapaian pedestrian menjadi lebih mudah. Dari tapak tersebut dianalisa mengenai potensi-potensi yang ada di sekitar tapak, dimulai dari vista tapak, sirkulasi jalan, sirlukasi entrance, integrasi ruang luar, potensi pedestrian dari transportasi publik, kondisi sekitar terkait dari suasana dan fasilitas sekitar tapak.

Dari latar belakang mengenai body positivity (lih. Gambar 3) tersebut kemudian diterjemahkan ke dalam sebuah ruang yang dimana terdapat 3 program utama yaitu adanya education, entertainment, dan Socialize. Education berupa gallery dengan exhibition space dan installation space yang menjelaskan mengenai penampilan fisik tubuh, gender sebagai identitas tubuh, indera, dll mengenai tubuh. Sedangkan playground memiliki tujuan untuk memaksimalkan pergerakan tubuh disamping adanya sirkulasi dalam bangunan. Lalu ada meeting point untuk berkumpul bersama, berelaksasi sambil bercengkrama dan membentuk komunitas di dalamnya diharapkan dengan adanya program ini terutama playground dan meeting point disi dapa dijadikan sebagai living room dalam kawasan ini. Pada gallery ini memiliki program yang salah satunya adalah exhibition. Exhibition disini sendiri pun bertemakan "body", dan memiliki susunan frame materi seperti gambar yang terlampir. Program utama pada proyek Gallery of Body and Space ini adalah wadah untuk edukasi mengenai tubuh yang berdampak body positivity dengan fasilitas program-program penunjang lainnya. Program di dalamnya terdapat 3 konsep utama, yaitu Learn, Play, dan Mingle. Presentase program di dalam proyek ini adalah Learn 35\%, Play 32\%, Mingle 20\%, dan fasilitas penunjang lainya $5 \%$ (lih.Gambar 4).

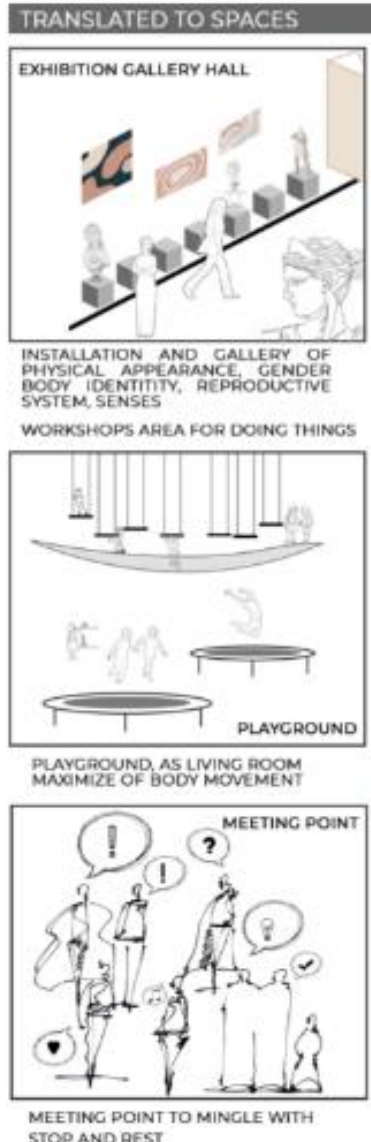

FOOD SPACE AS SUPPUER BOON NEEDS

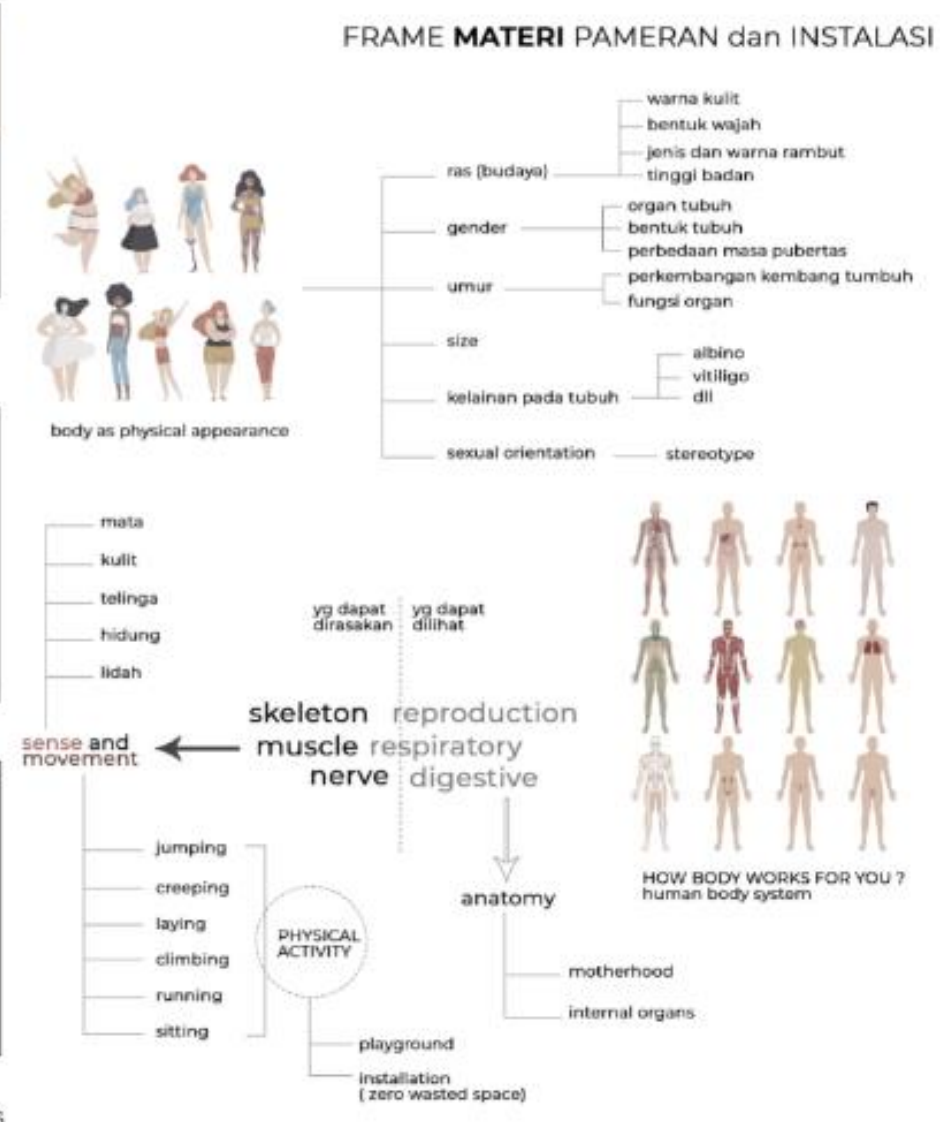

Gambar 3. Frame Materi Sumber: Penulis,2020. 


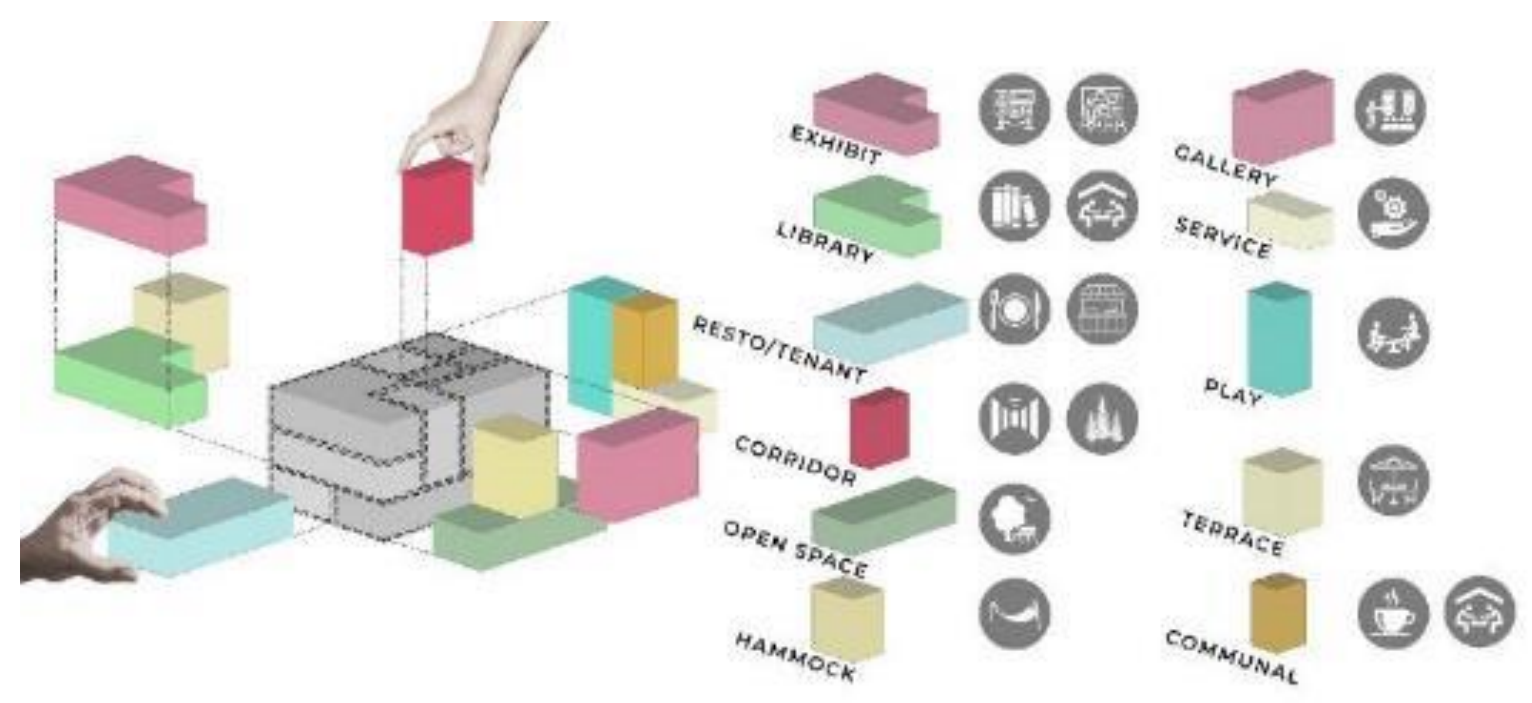

Gambar 4. Program

Sumber: Penulis,2020.

1. Learn: tempat yang mendukung program 'Education' untuk para pengunjung belajar, berkembang, menambah wawasan dan informasi mengenai tubuh dan keberagamannya. Ruang berupa perpustakaan digital/non digital, park as gallery, exhibition space, open theatre dan event space.

2. Play: tempat yang mendukung program 'Entertainment' pada third place, dimana pengunjung dapat bermain dengan tujuan menyadarkan bagaimana konteks tubuh dapat menyokong kegiatan dengan 'show how it works'. Selain itu menjadikan play ini sebagai ruang yang terbuka untuk bersosialisasi dengan stranger.

3. Mingle: kegiatan yang mendukung program 'Socialize', dimana pengunjung thirdplace bisa berbincang, terbukan akan pembicaraan mengenai tubuh, berkonsultasi dan bisa berbagi cerita dengan orang baru melalui komunitas yang terbangun. Ruang dapat berupa amfiteater area, food space, communal space, café, park, playscape, dan rooftop bar, pada intinya ruang yang mengakibatkan orang dpaat berkumpul dab berdiskusi.

Konsep massa awal berasal dari pergerakan tubuh manusia dari telungkup hingga berlari, yang dimana semua pergerakan itu menghasilkan frame yang kemudian ditangakap (captured) dan menghasilkan sebuah posisi tubuh manusia. Dari posisi inilah kemudian dijiplak (traced) dan menghasilkan bentukan-bentukan posisi tubuh manusia yang akan dijadikan base design pada gubahan massa. Selanjutnya dari bentukan tersebut di-extrude dan menghasilkan body position piece, dan disusun menjadikannya sebagai ruang void yang nantinya dijadikan sebagai cut out pada gubahan awal yang berbentuk kotak. Massa yang terbentuk setelah adanya substractive pada cut out dan massa awal balok makan akan terbentuk bagian-bagian yang menjadi void. Sebagian void dibuat tertutup dengan adanya lapisan transparan sebagai bukaan untuk ruang dalam (lih.Gambar 5). 


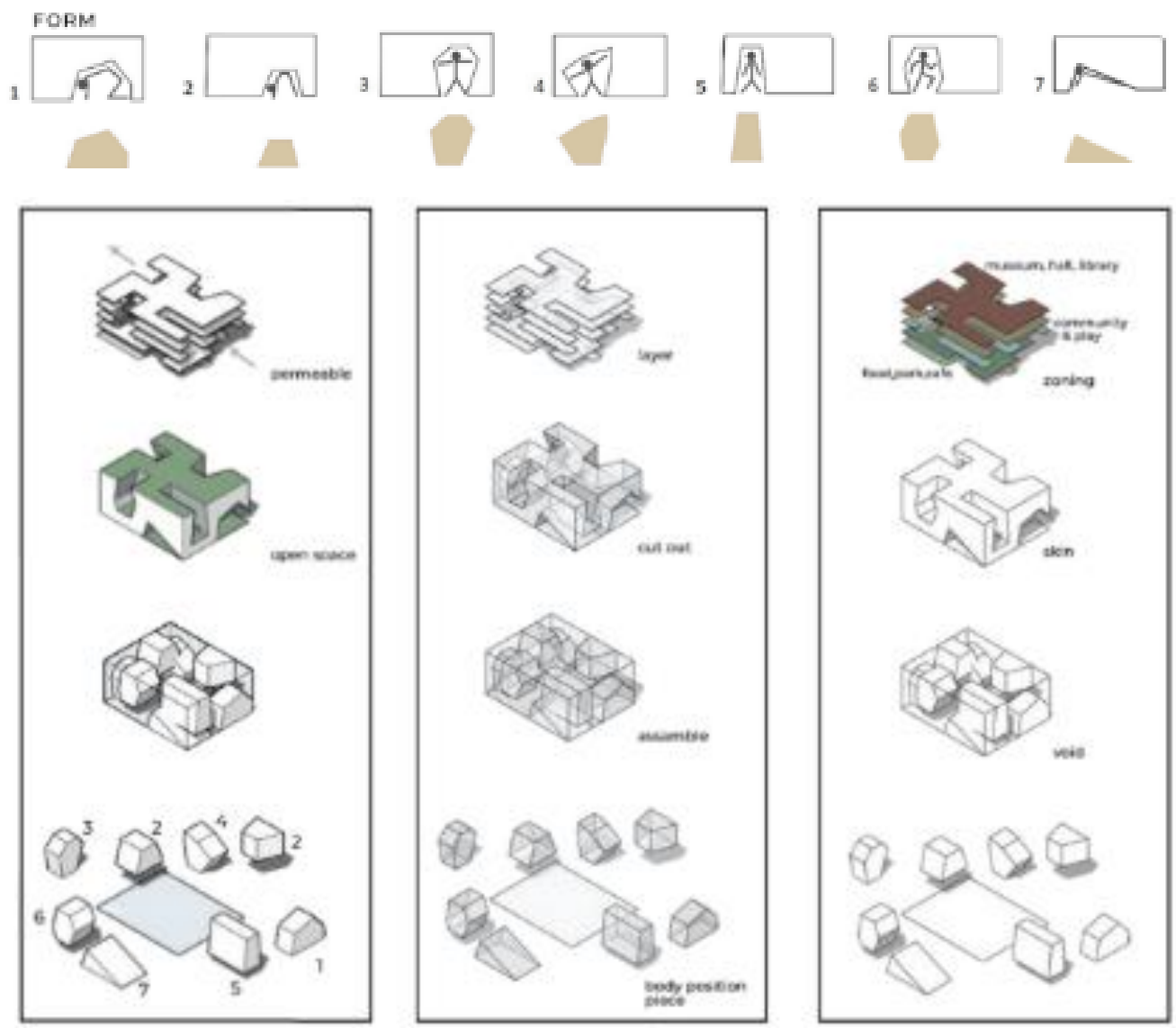

Gambar 5. Porses Gubahan Sumber: Penulis, 2020.

Secara vertikal bangunan memiliki zoning massa yang linear. Area lantai dasar merupakan area publik dan area rembesan dari second place ke first place dari kawasan. Dilanjutkan pada lantai 2 dan mezanin yang merupakan ruang komunal berupa working space, library dan café tempat dimana orang dapat berkumpul dan berdiskusi. Lantai 3 dan 4 merupakan kegiatan utama dari proyek yaitu adanya exhibition hall, installation space, dan play area yang secara vertikal (lih.Gambar 6). Lantai teratas merupakan area publik terbuka, dengan adanya roof top berupa playscape, bar dan taman. Play area disini dibentuk vertikal keatas sehingga memberikan suasana bermain dan bergerak yang lebih bervariasi. Pada bagian tengah bangunan memiliki sebuah open space berupa corridor yang menghubungkan ketiga void pada bangunan yang dijadikan sebagai outdoor area berupa terrace dan amphiteater.

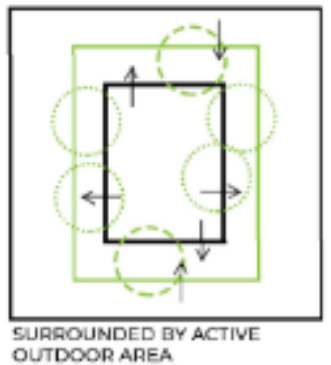

OUTDOOR AREA

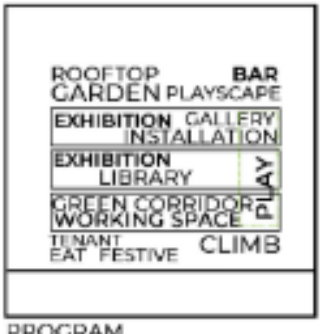

PROCRAM

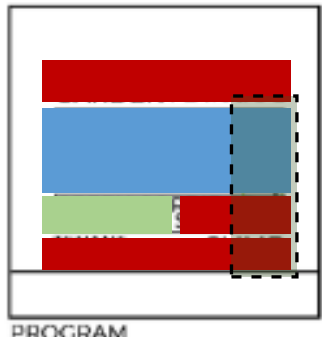

PROCRAM

Gambar 6. Zoning Massa

Sumber: Penulis,2020. 
Dari gubahan massa yang terbentuk memiliki 3 void pada lantai atas yang dimana 3 void tersebut kemudian difungsikan sebagai ruang terbuak luar yang dihubungkan dengan sebuah corridor (berwarna kuning) sehingga terbangun koneksi diantara ketiganya dan membangun pengalaman ruang yang berbeda di dalamnya dengan adanya pemecahan sirkulasi manusia menjadi 3 bagian. Hal ini diharapkan supaya movement manusia dapat mendefinisikan ruang dan tubuh dapat menciptakan pengalaman ruangnya sendiri. Corridor ini diberi nama green corridor karena di fungsikan sebagai ruang terbuka berupa taman yang terhubung ke ruang terbuka luar berupa hammock terrace, outdoor terrace, dan amfiteater yang tergabung untuk menciptakan linkage pada bangunan (lih. Gambar 7). Sirkulasi manusia yang ke dalam bangunan memiliki alur yang berbeda-beda dengan setiap kepentingannya, sehingga menggambarkan adanya hybrid program di dalam proyek dengan diveristas program dan konfigurasi ruang yang saling berkolerasi.
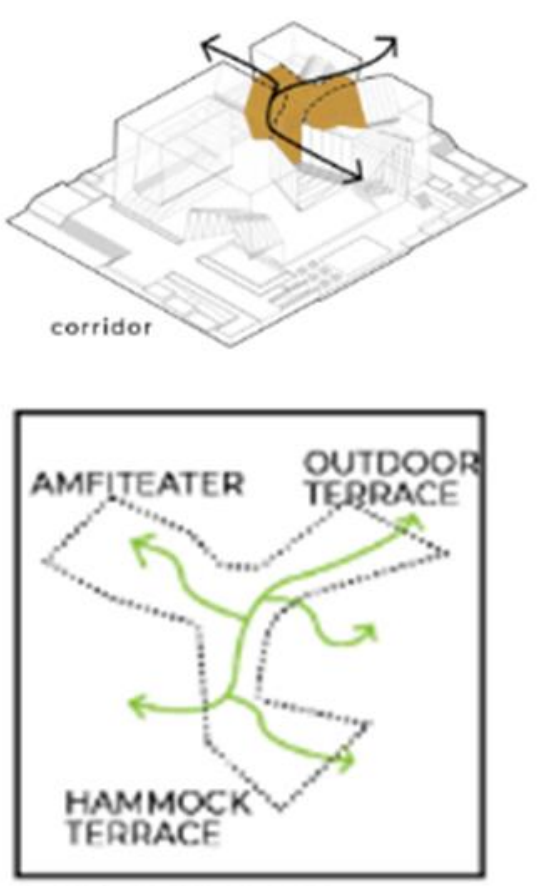

GAEEN CORRIDOR

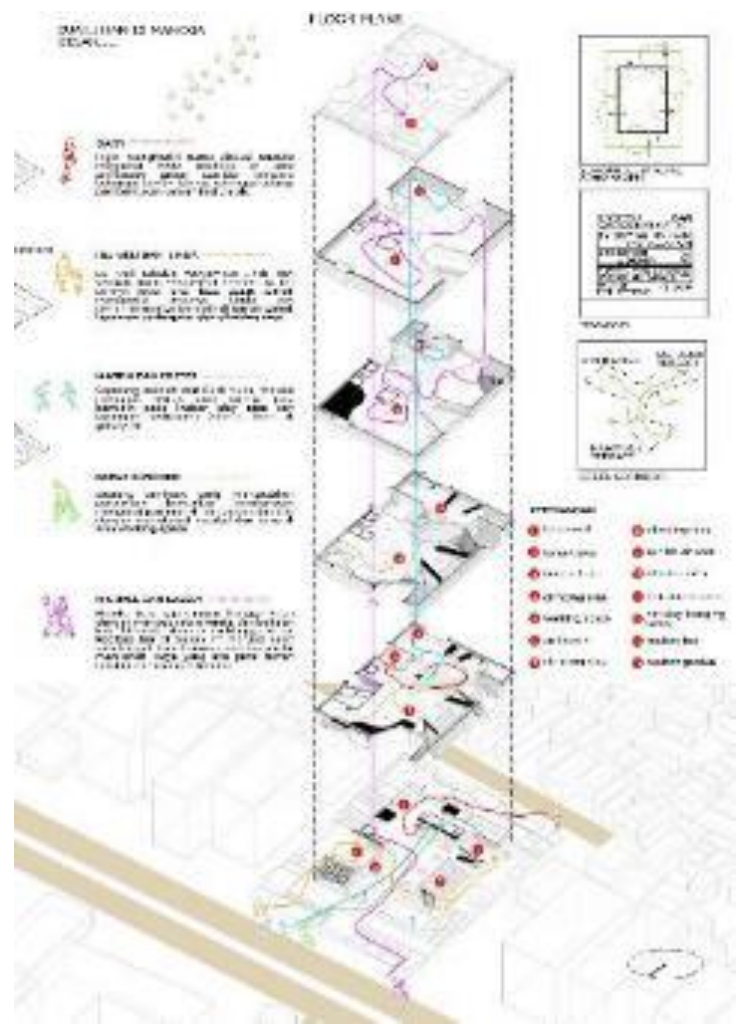

Gambar 7. Konsep Green Corridor (Kiri) dan Konsep Sirkulasi Bangunan (Kanan) Sumber: Penulis,2020.

Struktur utama pada bangunan menggunakan kolom $\mathrm{H}$ dan balok I yang berbahan baja dengan berbagai ukuran sesuai dengan bentang. Kemudian dilanjutkan dengan mega struktur pada green corridor dan void yang disambungnya, menggunakan material komposit pada bagian kolom yang berbentuk lebih organik dan pada bagian badan dari green corridor menggunakan struktur space frame. Pada bagian tampak terdapat void-void yang terbentuk ruang dengan ditopang oleh struktur rangka bidang dengan bahan pipa besi berdiameter $50 \mathrm{~mm}$. sedangkan pada bagian façade bangunan menggunakan second skin berbahan timber dengan ditopang oleh struktur rangka hollo ukuran 5/10 yang bertopang kepada struktur utama kolom dan balok. Pada bagian roof top menggunakan kanopi yang berbentuk seperti payung dengan struktur utama berbahan pipa besi, dan pada pentupnya menggunakan rangka besi yang dilapisi oleh ACP dan juga laminated glass. 


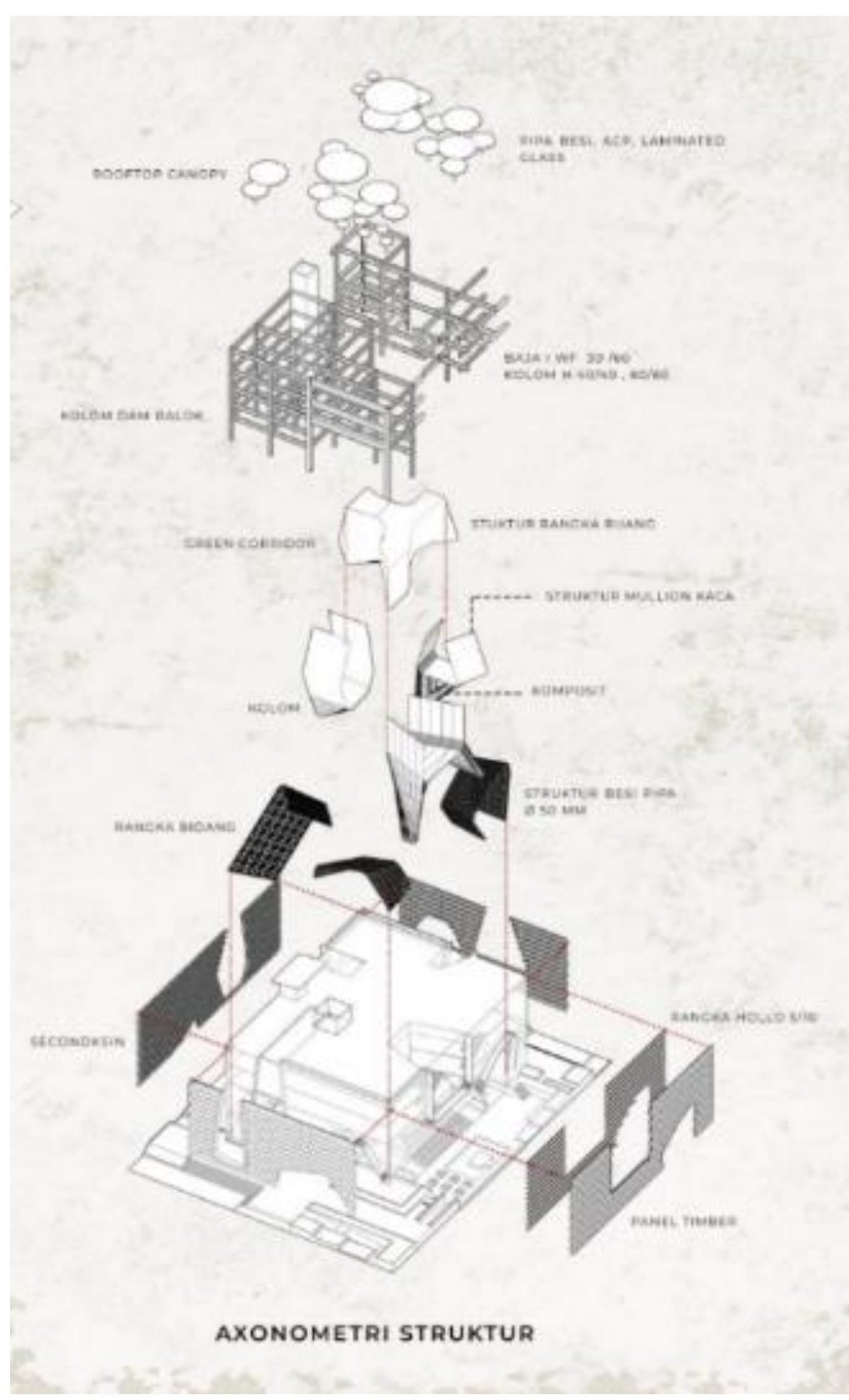

Gambar 9. Exploded struktur

Sumber: Penulis,2020.

Dalam menyusukseskan Sustainable Development Goals, proyek ini menggunakan material Cross Laminated Timber (CLT) sebagai material utama pada façade bangunan. CLT ini dipilih karena memiliki berbagai keunggulan dan salah satunya adalah ramah lingkungan. Selain itu memberikan wajah baru pada kawasan yang didominasi oleh bangunan yang bermaterialkan kaca dan beton, sehingga memiliki perbedaan dari bangunan di lingkungan sekitarnya. Hasil analisa kawasan menunjukkan bahwa kurangnya wajah hijau kota, sehingga material kayu dirasa cocok untuk memberikan kesan natural dan green pada wajah kota di kawasan ini. Selain itu pengrgunaan panel CLT ini dirancang dengan sistem cross ventilation sehingga pengudaraan dalam ruangan tetap sejuk dan mengurangi pemakaian energi. 


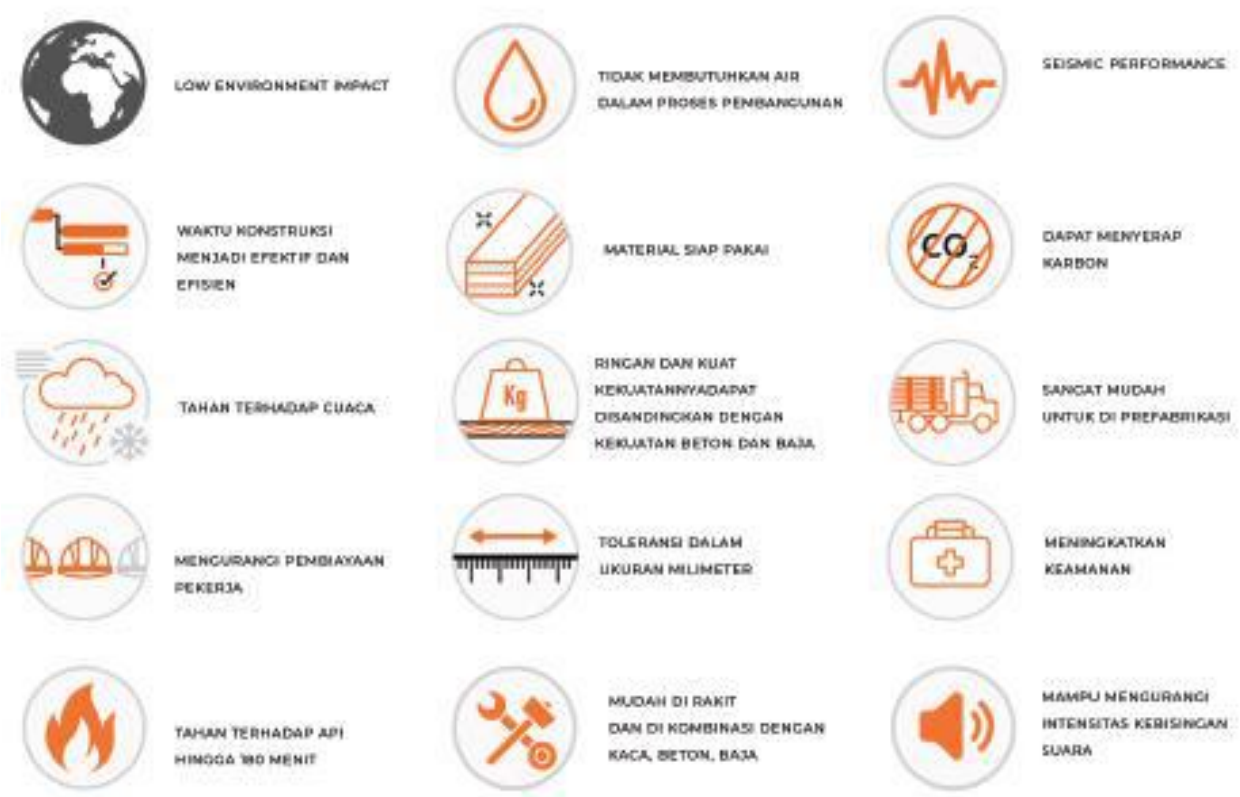

Gambar 10. Keuntungan Material Cross Laminated Timber Sumber: e-book Solid Timber Construction

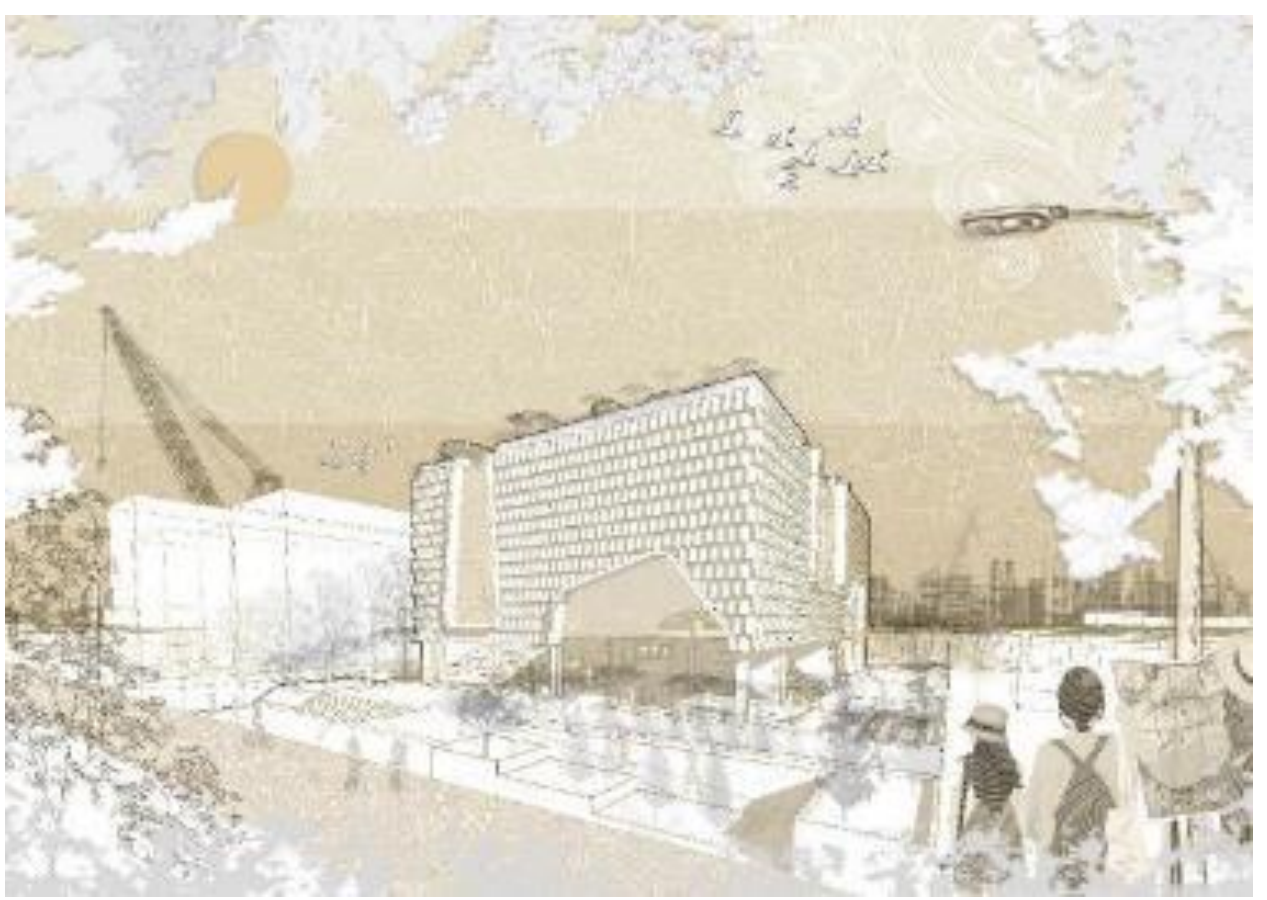

Gambar 11. Penggunaan Material Timber pada Facade Sumber: Penulis, 2020

\section{KESIMPULAN DAN SARAN}

\section{Kesimpulan}

Third place dalam sebuah kota menjadi suatu bagian yang vital dimana tempat ini dapat dijadikan sebagai ruang dimana manusia dalam kota dapat berinteraksi dengan sesamanya di luar lingkungan first place dan second place mereka. Fungsi gallery yang bersifat edukasi dinilai cukup baik untuk menciptakan suasana ruang ketiga kota yang berada pada kawasan Mangga Besar, dilihat dari fungsi di sekitar tapak di samping banyak komersial namun juga fungsi sosial seperti rumah sakit, dan terutama banyak sekolah di area kelurahan ini. Tema Body and Space ini terambil dari background kawasan Mangga Besar itu sendiri, yaitu isu prostitusi yang 
berhubungan dengan adanya makna mengahargai tubuh dari nilai sosial yang ada. Kemudian munculah sebuah latar belakang provokatif berupa konsep body positivity yang dimana menjadi ide dasar pada thirdplace di kawasan Mangga Besar.

Sebuah gallery diharapkan dapat menjadi sarana edukasi sekaligus entertainment dalam kawasan supaya dapat meningkatkan pengetahuan mengenai keberagaman dan bagaimana tubuh dapat bekerja untuk kita yang akan diterjamahkan kedalam program-program dalam bangunan. Salah satunya adalah Play, dimana bermain membutuhkan tubuh yang bergerak dengan berbagai macam movement sehinngga menunjukkan bagaimana tubuh dapat begrerak dan menghasilkan gerakan melalui arsitektur sekaligus mendapatkan pengalaman ruang yang dihasilkan oleh arsitektur. Selanjutnya ada program mingle / socialize, yang dimana diharapan di thirdplace ini dijadikan sebagai meeting point yang dimana di dalamnya dapat terbentuk komunitas-komunitas dan salah satunya adalah komunitas penggerak body positivity. Selain itu third place ini dijadikan sebagai open space untuk masyarakat sekitar untuk melakukan sharing, berkarya, bercengkrama, dan dianggap sebagai living room pada sebuah urban society.

\section{Saran}

Dalam perancangan yang bertemakan third place ini perlu diperhatikan beberapa aspek penting yang menjadi poin-poin penting dalam fungsi dan karakteristik ruang ketiga pada kota. Selain itu juga diperlukannya pemahaman mengenai konteks karakteristik kawasan yang dapat dimplementasikan ke dalam desain sebuah third place supaya mempertahankan kekhasan baik kawasan maupun masyarakat di dalamnya.

\section{REFERENSI}

Astarto, M. A. (2008). Hubungan Antara Locus of Control dengan Ketidakpuasan Akan Bentuk Tubuh Remaja Wanita, Sarjana Psikologi Universitas Indonesia. Diunduh 1 Juli 2020, dari http://lib.ui.ac.id/file?file=digital/125494-153.73\%20AST\%20h\%20\%20Hubungan\%20Antara-Pendahuluan.pdf

Herlambang, S. (2020, Februari). Open Architecture. Bahan Kuliah Umum di Universitas Tarumanagara, Jakarta, Indonesia.

Jain, S. K. (2017). Dance \& Architecture: Choreographing Engagement between Body \& Space Dessertation. Published Thesis, Bachelor of Architecture Mumbai University, diunduh 26 Juni 2020, dari https://issuu.com/sukrutijain/docs/dance__architecture_-_choreographi

Journeaux, J., Gorrill, H. \& Reed, S. (2020). Body, Space, and Palce in Collaborative Drawing: Drawing Conversations II. New Castle, United Kingdom: Cambridge Scholars Publishing.

Kirnandita, P. (2017), Belajar Mencintai Tubuh Sendiri Itu Seksi, diunduh 3 Juli 2020, dari https://tirto.id/belajar-mencintai-tubuh-sendiri-itu-seksi-cmkl

Kumarawansa, D. (2015). Body, Movement, Architecture. (Published Thesis). Master of Architecture (Professional) School of Architecture, Victoria University of Wellington. Wellington. 9-17

Oldenburg, R. (1999). The Great Good Place. New York: Da Capo Press.

Pallasmaa, J. ( $3^{\text {rd }}$ Revised edition, 2012.) The Eyes of the skin: Architecture and the sense. New Jersey, United Kingdom: John Wiley \& Sons.

Rodriguez, A. S. (2019). The Space Moulded by The Body, Bartlett School of Architecture, United Kingdom, diunduh 1 Juli 2020, dari http://www.interactivearchitecture.org/thespace-moulded-by-the-body.html

Sutanto, A. (2020, Februari). Open Architecture: Third Place. Bahan Kuliah Umum di Univesitas Tarumanagara, Jakarta, Indonesia.

Tjahjono, G. (2000). Metode Perancangan: Suatu Pengantar untuk Arsitek dan Perancang. Depok: Universitas Indonesia. 
Uysal, V. and Markus W. (2001). Embodying architecture, studying dance: movement as means of studying bodyspace relationship. Turkey: University of Bilkent. 